\title{
OTRI 0 - Diagnóstico diferencial para detecção de herpesvírus humanos em pacientes imunocomprometidos
}

Amanda de Oliveira Lopes ${ }^{1 *}$; Adilson José de Almeida ${ }^{2}$; Fernando Samuel Sion$^{2}$; Carlos Alberto Morais-de-Sá2; Vanessa Salete de Paula ${ }^{1}$

1 - Lab. de Desenvolvimento Tecnológico em Virologia, Instituto Oswaldo Cruz, Fiocruz;

2 - Hospital Universitário Gaffrée e Guinle, Unirio.

\section{Introdução:}

Os herpesvírus humanos (herpes simples tipo 1 e 2, varicela-zoster, Epstein -Barr, citomegalovírus humano, bem como herpesvírus humanos dos tipos 6A/B, 7 e 8) são responsáveis por causar uma variedade de doenças. Porém os quadros de infecção grave ocorrem, geralmente, em indivíduos imunocomprometidos, como os portadores do vírus da imunodeficiência humana (HIV). Com isso, são necessários métodos de diagnóstico rápido, proporcionando a informação para o tratamento do paciente e o controle da infecção. Entretanto os métodos utilizados para detecção dos herpesvírus humanos (HHV) devem ser reproduzidos diversas vezes para a diferente detecção dos nove vírus, podendo ocasionar uma demora no diagnóstico.

\section{Objetivo:}

Avaliar a co-infecção herpesvírus humanos/HIV através de um diagnóstico diferencial por PCR que permite a detecção simultânea dos nove vírus da família Herpesviridae que infectam humanos e avaliar fatores associados com a prevalência dessas co-infecções, como sexo, idade e taxas de CD4/CD8.

\section{Metodologia:}

Foi realizado um estudo retrospectivo que compreendeu 112 amostras de soro de pacientes HIV reagentes coletadas durante o ano de 2012 provenientes do Hospital Universitário Gaffrée e Guinle/HUGG - Rio de Janeiro. As amostras foram testadas por PCR qualitativo, através de um PCR convencional seguido por um nested PCR, a partir da amplificação da região genômica conservada da DNA polimerase (dPOL/ 160-181 pares de bases). As amostras que amplificaram a região dPOL dos herpesvírus no PCR qualitativo foram submetidas ao sequenciamento do DNA viral para determinar a sequencia dessa região e, assim, identificar o herpesvírus humanos que foi detectado. 


\section{Resultados:}

Neste estudo foi encontrada uma prevalência da co-infecção HHV/HIV de $29 \%$ (32/112), sendo que entre as amostras positivas $91 \%$ (29/32) estavam relacionadas a coinfecção HSV-1/HIV e 9\% (3/32) estavam relacionadas a coinfecção HHV-6/HIV. Logo, foi identificado uma prevalência da co-infecção de HSV-1/HIV de 26\% (29/112) e uma coinfecção de HHV-6/HIV de 3\% (3/112). A média da taxa de CD4 foi menor nos pacientes co-infectados $(498,63) \mathrm{com}$ parado aos pacientes sem co-infecção $(597,36)$. As variáveis sexo, idade, taxas de CD4/CD8 não tiveram associação com a detecção de herpesvírus humanos nas amostras de soro dos pacientes HIV reagentes.

\section{Conclusão:}

A utilização do PCR para a detecção simultânea dos herpesvírus foi relevante para diagnosticar a infecção do HSV-1 e HHV-6 em pacientes portadores do vírus HIV no Rio de Janeiro, permitindo monitorar o quadro clínico do paciente, além de colaborar para determinação da prevalência de infecções causadas pelos herpesvírus humanos no Brasil.

Palavras-Chave: Herpesvírus humanos, diagnóstico diferencial, prevalência, pacientes HIV reagentes 